\title{
EFEKTIFITAS UNDANG - UNDANG KEPABEANAN TERHADAP PENANGGULANGAN PENYELUNDUPAN SEMBAKO DI KOTA BATAM
}

\author{
Rufinus Hotmaulana Hutauruk*, Dedi Susanto ${ }^{* *}$ \\ Fakultas Hukum, Universitas International Batam
}

\begin{abstract}
The purpose of this research is to analyze the law against groceries smuggling in Batam City. It also aims to establish the legal settlement against smuggling perpetrators in Batam City. Data collected for this study is carried out by the field studies and library research. The result of research is that the function of the Customs and Excise in Batam City which deals with the supervisory functions. Have faced many hindraces, especially because of the geographical condition of Batam City and the high consumptive behavior of Batam society which make it very difficult to control the smuggling of groceries in Batam City. In addition, due to the irresponsible persons in the port who receive bribery have weakened the surveillance capacity against smuggling.
\end{abstract}

Keywords: groceries, customs, smuggling.

Abstrak
Tujuan dari penelitian ini adalah untuk menganalisis hukum terkait penyelundupan bahan makanan di Kota Batam. Penelitian ini juga bertujuan untuk menemukan penyelesaian hukum terhadap pelaku penyelundupan di Kota Batam. Data yang dikumpulkan untuk penelitian ini dilakukan melalui studi lapangan dan penelitian kepustakaan. Hasil penelitian adalah bahwa fungsi Bea dan Cukai di Kota Batam berkaitan dengan pengawasan banyak mengalami kendala, terutama karena kondisi geografis Kota Batam dan tingginya perilaku konsumtif masyarakat Batam membuat sangat sulit untuk mengendalikan penyelundupan bahan makanan di Kota Batam. Selain itu, karena orang-orang yang tidak bertanggung jawab di pelabuhan yang menerima suap telah melemahkan kapasitas pengawasan terhadap penyelundupan.

Keyword: sembako, Bea Cukai, penyelundupan.

\section{A. Latar Belakang Masalah}

Indonesia adalah sebuah negara. Terbentuknya sebuah negara dengan adanya wilayah, rakyat, pemerintahan, dan kedaulatan dari negara lain. Negara dalam upayanya untuk mensejahterakan rakyat membutuhkan biaya yang tidak sedikit. Untuk itu diperlukan sumber-sumber dana bagi keuangan Negara. Adapun salah satu sumber dana tersebut, berasal dari pungutan Bea dan pungutanpungutan lain yang sah. Dalam pelaksanaannya pungutan tersebut antara lain dibebankan pada aparat pemerintah tersendiri antara lain yaitu Direktorat Jenderal Bea dan Cukai yang berada di bawah naungan Kementrian Keuangan.

*Alamat korespondensi : rufinushotmaulana@yahoo.com

Alamat Korespondensi : dedi.santo1@gmail.com 
Direktorat Jenderal Bea dan Cukai diberi tugas untuk mengatur masuknya barang dari luar negeri ke dalam negeri atau impor dan keluarnya barang dari dalam negeri ke luar negeri atau ekspor. Dalam aktifitas perekonomian terdapat kecenderungan untuk mengejar keuntungan sebesar-besarnya sehingga tidak mustahil terdapat penyimpangan dalam ekspor atau impor dalam rangka menghindarkan dari pungutan-pungutan bea dan pungutan lainnya. Hal ini sangat mungkin terjadi mengingat kondisi geografis Negara Indonesia terdiri dari

Puluhan ribu pulau yang terdiri dari pulau-pulau besar maupun pulau-pulau kecil. Antara pulau-pulau tersebut terbentang jarak yang berbagai macam antar satu pulau dengan pulau lain maupun antar pulau di wilayah Indonesia dengan pulau wilayah negara lain ${ }^{1}$.

Saat ini perdagangan internasional memiliki perkembangan yang baik menyangkut kegiatan di bidang impor juga ekspor. Kondisi ini mengalami kemajuan yang sangat pesat. Kemajuan di bidang tersebut sangat pesat serta membuat suatu sistem operasional lebih sangat efektif dan efisien. Selain itu juga mampu meningkatkan kelancaran jalur barang dan dokumen. Oleh karena itu, masalah birokrasi di bidang kepabeanan yang sulit dan berbelit - belit merupakan permasalahan yang nantinya akan semakin tidak populer. Dengan kondisi seperti itu, tentunya tidak terlepas dari pentingnya efektifitas pemerintah untuk terus membuat berbagai kebijaksanaan di bidang ekonomi dalam meningkatkan perekonomian nasional.

Perbedaan jarak yang lebih dekat dengan luar negeri dari pusat perdagangan dalam negeri, perbedaan harga yang menyolok antar harga barang di dalam negeri dengan harga barang di luar negeri, mentalitas oknum-oknum tertentu, kelemahan sarana dan prasarana serta kelemahan administrasi berupa berbelitnya birokrasi sehingga dapat memberikan peluang pada pihak-pihak yang melakukan kegiatan. Ekspor impor untuk melakukan penyimpangan-penyimpangan dan pelanggaranpelanggaran. Salah satu bentuk dari penyimpangan dan pelangaran tersebut adalah tindak pidana penyelundupan.

Tindak pidana penyelundupan menjadi masalah yang serius dalam pelaksanaan perekonomian negara, hal ini disebabkan karena apabila penyelundupan semakin meningkat dengan berbagai bentuk baik secara fisik, maupun secara administratif, akan menyebabkan semakin banyak uang negara yang tidak terpungut sehingga akan menghambat baik itu target yang ditetapkan negara melalui pungutan bea dan cukai yang setiap tahunnya di harapkan meningkat. Setiap tahun selalu saja terjadi kerugian akibat penyelundupan yang terjadi di wilayah Indonesia baik itu melalui jalur darat, laut maupun udara.

1 Aridhayandi, M. R.. Kajian dalam Penerapan Sanksi Pidana terhadap Pelaku yang Melakukan Perbuatan Curang dalam Bisnis Dihubungkan dengan Pasal 379a Kitab UndangUndang Hukum Pidana, 8(65),2017, Hal.80-92. 
Tindak pidana penyelundupan disebabkan oleh beberapa faktor di antaranya faktor geografis, pasar produksi dan masyarakat. Secara geografis, Indonesia terdiri dari beribu-ribu pulau, letak Indonesia dipersimpangan jalan dua benua dengan garis pantai yang luas dengan negara-negara yang sudah maju di bidang Industri, memberikan kesempatan atau peluang, bahkan merangsang para pengusaha di luar negeri untuk melakukan perbuatan melawan hukum dengan cara memasukkan barang-barang secara ilegal ke wilayah hukum Republik Indonesia. Indonesia sebagai negara berkembang, berkeinginan mengandalkan sektor industrinya sendiri, namun sektor industri tersebut masih jauh dari yang diharapkan, sedangkan negara-negara di sekitar Indonesia yang sudah maju dibidang industrinya seperti Jepang, Taiwan, dan lainnya kesulitan dalam pemasaran hasil industri.

Indonesia dengan jumlah penduduk yang padat, membuat negara-negara di sekitar Indonesia yang maju dalam bidang industri tersebut mendapat kesempatan atau peluang untuk memasarkan hasil industrinya tersebut ke Indonesia dengan melakukan berbagai cara pemasarannya termasuk dengan perbuatan melawan hukum seperti dengan cara mengekspor barang dari negaranya dengan memberikan data yang tidak benar pada saat membuat dokumen untuk barangbarang yang masuk ke Indonesia atau bahkan melalui penyelundupan murni. Upaya penanggulangan masalah penyelundupan, dihadapkan pada kendala yaitu masyarakat kurang memberikan partisipasinya, meskipun media massa cukup memuat berita-beritatentang penyelundupan, tetapi masyarakat masih tetap pasif, karena merasa beruntung dapat membeli barang-barang secara murah dengan mutu yang tinggi. Masyarakat Indonesia yang masih international minded, artinya lebih memilih produk-produk luar negeri, yang sesungguhnya tidak kalah bagus mutunya dengan hasil produksi dari dalam negeri.

Tabel 1.1. Temuan kasus penyelundupan yang berhasil di cegah di Indonesia Tahun Periode 2013-2015

\begin{tabular}{|l|l|l|l|l|}
\hline \multirow{2}{*}{ No } & \multirow{2}{*}{ Jenis Komoditi } & \multicolumn{3}{|l|}{ Jumlah Penindakan (Kasus) } \\
\cline { 3 - 5 } & & 2013 & 2014 & 2015 \\
\hline 1 & Tekstil dan produk tekstil & 216 & 293 & 563 \\
\hline 2 & Sembako(gula, beras, dan lain-lain) & 113 & 130 & 139 \\
\hline 3 & Elektronik & 117 & 197 & 304 \\
\hline 4 & Narkoba (NPP) & 217 & 216 & 176 \\
\hline 5 & Obat-obatan dan bahan kimia & 298 & 441 & 1592 \\
\hline 6 & Bahan bakar minyak (BBM) & 8 & 10 & 9 \\
\hline 7 & Rokok dan Minol & 1077 & 1531 & 2199 \\
\hline 8 & Pakaian Bekas & 11 & 19 & 24 \\
\hline 9 & Lainnya & 3197 & 3803 & 5003 \\
\hline & Total & 5.254 & 6.640 & 10.009 \\
\hline
\end{tabular}

Sumber: Warta Bea Cukai , Direktorat Jenderal Bea dan Cukai Kementrian Keuangan RI 
Uraian di atas menunjukkan bahwa fenomena kejahatan di wilayah kepabeanan khususnya penyelundupan barang impor merupakan kejahatan yang harus ditanggulangi dengan serius, khususnya oleh instansi terkait yang dalam hal ini adalah Direktorat Jenderal Bea dan Cukai melalui kantor-kantor wilayah maupun kantor-kantor pelayanannya yang tersebar di berbagai daerah di wilayah Negara Kesatuan Republik Indonesia dengan membentuk bagian atau unit-unit khusus untuk menangani kasus kejahatan kepabeanan yang bertanggung jawab terhadap tugas-tugas penegakan hukum berkaitan tindak pidana kepabeanan.

\section{B. Perumusan Masalah}

1. Apakah Pengaturan Hukum terhadap Penyeludupan Sembako di Kota Batam sudah sesuai dengan Undang-Undang Kepabeanan?

2. Bagaimana Implementasi Penyelesaian Hukum Terhadap Penyeludupan Sembako di Kota Batam Menurut Undang - Undang Kepabeanan?

3. Faktor apa saja yang menjadi hambatan/kendala untuk mengurangi Penyeludupan Sembako di Kota Batam?

\section{Metode Penelitian}

Untuk mendapatkan suatu data yang akurat dan relevan dengan permasalahan yang akan diteliti. Metode pendekatan masalah yang digunakan dalam penelitian ini adalah pendekatan secara yuridis normatif dan yuridis empiris. Pendekatan metode yuridis normatif yaitu metode pendekatan penelitian yang dilakukan untuk mempelajari dan mengkaji serta menelaah peraturan perundangundangan, asas asas, teori-teori dan konsep-konsep yang berhubungan atau yang kaitannya dengan studi Upaya penanggulangan tindak pidana penyelundupan sembako oleh Bea dan Cukai wilayah Batam. Pendekatan yuridis empiris yaitu pendekatan berdasarkan pada fakta objektif yang didapatkan dalam penelitian lapangan berupa hasil wawancara dengan narasumber penelitian.

Populasi dalam penelitian ini adalah semua pihak yang terkait tentang Analisis Efektfitas Pemerintah Dalam Undang Undang Kepabeanan Terhadap Penyelundupan Sembako di Kota Batam dengan banyaknya jumlah populasi dalam penelitian ini maka tidak semua populasi akan diteliti secara menyeluruh. maka akan diambil sampel dari populasi secara Purposive Sampling yaitu teknik yang biasa dipilih karena alasan biaya, waktu, tenaga, sehingga tidak dapat mengambil dalam jumlah besar. Dengan metode pengambilan sampel ditentukan berdasarkan tujuan yang telah ditetapkan dengan melihat pada persyaratan-persyaratan antara lain : berdasarkan ciri-ciri utama dari obyek yang diteliti dan penentuan karakteristik populasi yang dilakukan dengan teliti melalui studi pendahuluan.

Pengumpulan data dilakukan dengan prosedur studi kepustakaan dan studi lapangan sebagai berikut:

a. Studi Pustaka Studi pustaka adalah prosedur yang dilakukan dengan serangkaian kegiatan seperti membaca, menelaah dan mengutip dari buku- 
buku literatur serta melakukan pengkajian terhadap ketentuan peraturan perundang-undangan terkait dengan permasalahan.

b. Studi Lapangan Studi lapangan adalah prosedur yang dilakukan dengan kegiatan wawancara (interview) kepada responden penelitian sebagai usaha mengumpulkan berbagai data dan informasi yang dibutuhkan sesuai dengan permasalahan yang dibahas dalam penelitian. Yang menjadi responden dalam penelitian ini adalah para pihak yang terkait untuk mencegah masuknya sembako ilegal ke wilayah Batam. dengan mengacu kepada, UndangUndang Nomor 10 Tahun 1995 tentang Kepabeanan. Undang-Undang Kepabeanan mulai berlaku 1 April 1996, dimuat di dalam Lembaran Negara Nomor 75 Tahun 1995 sebagaimana telah diubah dengan Undang-Undang Nomor 17 Tahun 2006 tentang Kepabeanan.

Untuk mempermudah analisis data yang telah diperoleh sesuai dengan permasalahan yang diteliti. Pengolahan data dilakukan dengan tahapan sebagai berikut:

a. Seleksi data, adalah kegiatan pemeriksaan untuk mengetahui kelengkapan data selanjutnya data dipilih sesuai dengan permasalahan yang diteliti dalam penelitian ini.

b. Klasifikasi data, adalah kegiatan penempatan data menurut kelompokkelompok yang telah ditetapkan dalam rangka memperoleh data yang benarbenar diperlukan dan akurat untuk dianalisis lebih lanjut.

Penyusunan data, adalah kegiatan menyusun data yang saling berhubungan dan merupakan satu kesatuan yang bulat dan terpadu pada sub pokok bahasan sehingga mempermudah interpretasi data.

Analisis data yang dipergunakan dalam penelitian ini adalah analisis kualitatif dan penarikan kesimpulan dilakukan dengan metode induktif, yaitu menguraikan halhal yang bersifat khusus dalam bentuk kuisioner lalu menarik kesimpulan yang bersifat umum sesuai dengan permasalahan yang dibahas dalam penelitian.

\section{Hasil Penelitian dan Pembahasan}

Hasil wawancara yang dilakukan oleh peneliti dapat diuraikan dibawah ini :

1. M. Isman adalah seorang pegawai negeri sipil yang bertugas di Direktorat Jenderal Bea dan Cukai di Kantor Pelayanan Bea dan Cukai Tipe B Kota Batam, yang mengatakan sebaiknya pemerintah harus melakukan pengawasan / pembinaan importer secara berkesinambungan dan memberikan sanksi yang tegas tanpa pendang bulu, dan mengenai penyeludupan sembako di kota batam dapat merusak tatanan perdagangan local dan merusak produksi dalam negeri yang dapat mempernaruhi pola hidup masyarakat. Menurut M. Isman untuk mengantisipasi penyeludupan dikota batam harus melakukan pengawasan proses importasi untuk meningkatkan produksi dalam negeri dan harus menjaga stabilitas harga dan pasokan. Untuk menjaga agar masalah ini tidak terjadi pemerintah harus menjaga pasokan dan harga agar tetap stabil dan melakukan penertiban atas kepatuhan pelaksanaan peraturan. Untuk perlakuan terhadap infortir pemerintah harus mengawasi secara terus menerus 
kegiatannya dan ditindak dengan tegas bila melanggar aturan. Mengenai dampak positf pada mayarakat menurut $\mathrm{M}$. Isman tidak ada dampak positifnya untuk tindakan penyelundupan yang sering terjadi di kota batam, dan dampak negatifnya dapat merusak tatanan kehidupan, perdagangan dan perekonomian. Didalam penyeludupan ini kemungkinan akan terjadi akibat hilangnya kesempatan perdagangan secara baik, hilangnya lapangan pekerjaan dan meningkatnya Inflasi. Pemerintah dipandang belum efektif dalam melakukan penyelesaian terhadap penyeludupan ini. Factor - factor yang menjadi kendala dan hambatan dalam penyelesaian penyeludupan di kota batam dikarenakan masih adanya Kartel yang mendominasi Perdagangan serta belum adanya penegakkan hukum yang jelas. Untuk mengatasi ini semua hendaknya pemerintah membuat kepastian hukum yang jelas dan peranan pemerintah cukup baik hanya belum didukung komitmen yang cukup dari pelaku pasar.

2. Budi Mulyono adalah seorang pegawai negeri sipil yang bertugas di Direktorat Jenderal Bea dan Cukai di Kantor Pelayanan Bea dan Cukai Tipe B Kota Batam, yang mengatakan sebaiknya pemerintah harus melakukan pengawasan / pembinaan importer secara berkesinambungan dan memberikan sanksi yang tegas tanpa pendang bulu, dan mengenai penyeludupan sembako di kota batam dapat merusak tatanan perdagangan local dan merusak produksi dalam negeri yang dapat mempernaruhi pola hidup masyarakat. Menurut Budi Mulyono untuk mengantisipasi penyeludupan dikota batam harus melakukan pengawasan proses importasi untuk meningkatkan produksi dalam negeri dan harus menjaga stabilitas harga dan pasokan. Untuk menjaga agar masalah ini tidak terjadi pemerintah harus menjaga pasokan dan harga agar tetap stabil dan melakukan penertiban atas kepatuhan pelaksanaan peraturan. Untuk perlakuan terhadap infortir pemerintah harus mengawasi secara terus menerus kegiatannya dan ditindak dengan tegas bila melanggar aturan. Mengenai dampak positf pada mayarakat menurut Budi Mulyono tidak ada dampak positifnya untuk tindakan penyelundupan yang sering terjadi di kota batam, dan dampak negatifnya dapat merusak tatanan kehidupan, perdagangan dan perekonomian. Didalam penyeludupan ini kemungkinan akan terjadi akibat hilangnya kesempatan perdagangan secara baik, hilangnya lapangan pekerjaan dan meningkatnya Inflasi. Pemerintah dipandang belum efektif dalam melakukan penyelesaian terhadap penyeludupan ini. Factor - factor yang menjadi kendala dan hambatan dalam penyelesaian penyeludupan di kota batam dikarenakan masih adanya Kartel yang mendominasi Perdagangan serta belum adanya penegakkan hukum yang jelas. Untuk mengatasi ini semua hendaknya pemerintah membuat kepastian hukum yang jelas dan peranan pemerintah cukup baik hanya belum didukung komitmen yang cukup dari pelaku pasar.

3. Indra adalah seorang pegawai negeri sipil yang bertugas di Direktorat Jenderal Bea dan Cukai di Kantor Pelayanan Bea dan Cukai Tipe B Kota Batam, yang mengatakan sebaiknya pemerintah harus melakukan pengawasan / pembinaan importer secara berkesinambungan dan memberikan sanksi yang tegas tanpa pendang bulu, dan mengenai penyeludupan sembako di kota 
batam dapat merusak tatanan perdagangan local dan merusak produksi dalam negeri yang dapat mempernaruhi pola hidup masyarakat. Menurut Gatot Subroto untuk mengantisipasi penyeludupan dikota batam harus melakukan pengawasan proses importasi untuk meningkatkan produksi dalam negeri dan harus menjaga stabilitas harga dan pasokan. Untuk menjaga agar masalah ini tidak terjadi pemerintah harus menjaga pasokan dan harga agar tetap stabil dan melakukan penertiban atas kepatuhan pelaksanaan peraturan. Untuk perlakuan terhadap infortir pemerintah harus mengawasi secara terus menerus kegiatannya dan ditindak dengan tegas bila melanggar aturan. Mengenai dampak positf pada mayarakat menurut Gatot Subroto tidak ada dampak positifnya untuk tindakan penyelundupan yang sering terjadi di kota batam, dan dampak negatifnya dapat merusak tatanan kehidupan, perdagangan dan perekonomian. Didalam penyeludupan ini kemungkinan akan terjadi akibat hilangnya kesempatan perdagangan secara baik, hilangnya lapangan pekerjaan dan meningkatnya Inflasi. Pemerintah dipandang belum efektif dalam melakukan penyelesaian terhadap penyeludupan ini. Factor - factor yang menjadi kendala dan hambatan dalam penyelesaian penyeludupan di kota batam dikarenakan masih adanya Kartel yang mendominasi Perdagangan serta belum adanya penegakkan hukum yang jelas. Untuk mengatasi ini semua hendaknya pemerintah membuat kepastian hukum yang jelas dan peranan pemerintah cukup baik hanya belum didukung komitmen yang cukup dari pelaku pasar.

4. Anita. S adalah seorang Pengusaha Ekspor / Impor tinggal di Kota Batam Mengatakan sebaiknya pemerintah memberikan sanksi yang tegas terhadap pelaku penyeludupan sesuai dengan pelanggaran terutama di bidang kepabeanan yang dapat menimbulkan kerugian Negara dan masyarakat karena akan merusak harga dipasaran, batam yang berdampingan langsung dengan Negara tetangga sangat rawan penyeludupan maka pemerintah dalam hal ini direktorat jenderal bea dan cukai aktif dalam mencegah penyeludupan dengan meperbanyak armada dan patrol di laut. Yang bisa dilakukan pemerintah meninjau ulang undang - undang mengingat batam merupakan kawasan bebas FTZ. Dampak Positifnya yang dapat menguntungkan masyarakat yang sudah terbiasa mengkonsumsi barang dari luar, kerugian dibidang perdagangan karena akan merusak harga barang local, terjadi kerugian Negara karena barang yang masuk tanpa Bea Masuk. Pemerintah diharapkan mendata ulang pelabuhan yang ada di Kota Batam kaena banyaknya pelabuhan rakyat atau pelabuhan yang tidak resmi yang rawan penyeludupan. Anita. S. Berpendapat sangat setuju supaya Pelabuhan Rakyat agar mengurangi resiko terjadinya penyeludupan. Faktor - factor yang menghambat masyarakat Kota Batam yang sudah terbiasa mengkonsuksi barang dari luar negeri yang dimanfaatkan oleh infortir nakal, fakta yang terjadi dilapangan karena lemahnya Penegakkan Instansi Terkait Baik dilaut maupun di darat, sehingga terjadinya dualisme BP Batam dan Pemko Batam, pemerintah belum bisa menjalankan undang undang FTZ sehingga memicu terjadinya penyeludupan ini. Ini di karenakan Peralatan Pemerintah kurang memadai dibandingkan dengan Pelaku Penyelundupan sehingga penyeludupan terlalu longgar. 
5. Erfan adalah seorang Pedagang di Pasar Pagi Tanjung Uma tinggal di Kota Batam Mengatakan sebaiknya pemerintah memberikan sanksi yang tegas terhadap pelaku penyeludupan sesuai dengan pelanggaran terutama di bidang kepabeanan yang dapat menimbulkan kerugian Negara dan masyarakat karena akan merusak harga dipasaran, batam yang berdampingan langsung dengan Negara tetangga sangat rawan penyeludupan maka pemerintah dalam hal ini direktorat jenderal bea dan cukai aktif dalam mencegah penyeludupan dengan meperbanyak armada dan patrol di laut. Yang bisa dilakukan pemerintah meninjau ulang undang - undang mengingat batam merupakan kawasan bebas FTZ. Dampak Positifnya yang dapat menguntungkan masyarakat yang sudah terbiasa mengkonsumsi barang dari luar, kerugian dibidang perdagangan karena akan merusak harga barang local, terjadi kerugian Negara karena barang yang masuk tanpa Bea Masuk. Pemerintah diharapkan mendata ulang pelabuhan yang ada di Kota Batam kaena banyaknya pelabuhan rakyat atau pelabuhan yang tidak resmi yang rawan penyeludupan. Erfan Berpendapat sangat setuju supaya Pelabuhan Rakyat agar mengurangi resiko terjadinya penyeludupan. Faktor - factor yang menghambat masyarakat Kota Batam yang sudah terbiasa mengkonsuksi barang dari luar negeri yang dimanfaatkan oleh infortir nakal, fakta yang terjadi dilapangan karena lemahnya Penegakkan Instansi Terkait Baik dilaut maupun di darat, sehingga terjadinya dualisme BP Batam dan Pemko Batam, pemerintah belum bisa menjalankan undang undang FTZ sehingga memicu terjadinya penyeludupan ini. Ini di karenakan Peralatan Pemerintah kurang memadai dibandingkan dengan Pelaku Penyelundupan sehingga penyeludupan terlalu longgar.

Provinsi Kepulauan Riau merupakan Provinsi Ke-32 di Indonesia yang terbentuk berdasarkan Undang-Undang Nomor 25 Tahun 2002. Wilayah Kepulauan Riau terdiri dari: 5 Kabupaten, 2 Kota, 59 Kecamatan, 133 Kelurahan, serta 218 Desa dengan jumlah 2408 pulau, dimana 40\% dari pulau tersebut belum bernama dan berpenduduk. Provinsi Kepulauan Riau memiliki potensi yang besar untuk kegiatan bisnis dan investasi dalam berbagai sektor, diantaranya pertambangan (minyak dan gas bumi), pariwisata, perdagangan dan pelayanan/jasa. Provinsi ini memiliki batas wilayah sebagai berikut:

1. Utara dengan Vietnam dan Kamboja

2. Selatan dengan Provinsi Bangka Belitung dan Jambi

3. Barat dengan Singapura, Malaysia dan Provinsi Riau

4. Timur dengan Malaysia, Brunei, dan Provinsi Kalimantan Barat 


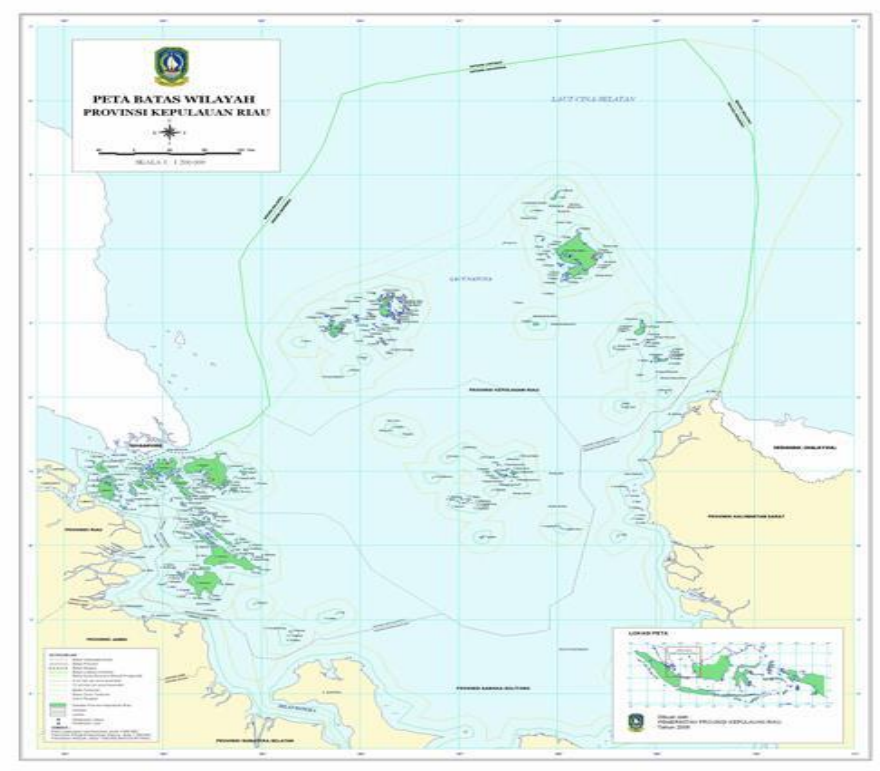

\section{Gambar 1. Peta Provinsi Kepulauan Riau}

Oleh karena itu jalur transaksi perdagangan international lebih mudah dilakukan karena letak geografis kepulauan riau yang sangat strategis yaitu jalur pelayaran dunia internasional.

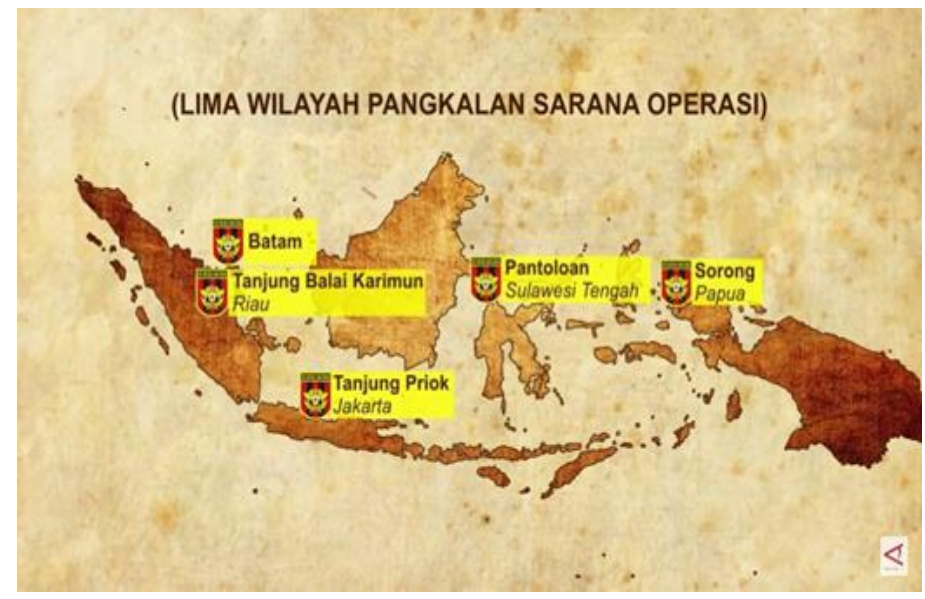

\section{Gambar 2. Wilayah Operasi Bea Cukai}

Dalam PMK Nomor 448/KMK.01/2001 tentang Organisasi dan Tata Kerja Pangkalan Sarana Operasi Bea dan Cukai, PSO pada Direktorat Jenderal Bea dan Cukai terbagi dalam dua tipe yaitu PSO tipe A dan PSO tipe B. Pada PSO tipe A dikepalai oleh seorang Kepala PSO yang membawahi Sub Bagian Umum, Seksi Nautika, Seksi Teknik dan Pemelihartaan kapal, Seksi Telekomonikasi, Seksi Penginderaan dan Kelompok Jabatan Fungsional. Susunan serupa juga terdapat pada PSO tipe B, hanya saja pada PSO tipe ini tidak memasukan Seksi penginderaan dalam susunan PSO. Struktur tersebut telah cukup memadai untuk 
memenuhi tugas pokok dan fungsi PSO sebagai UPT yang menunjang patroli dan operasi pencegahan dan penindakan dibidang kepabeanan dan cukai. Namun demikian tidak tertutup kemungkinan struktur tersebut diatur kembali dengan menyesuaikan kompleksitas tugas dan dinamika organisasi disamping untuk kepentingan efisiensi dan efektifitas. Tidak hanya itu luasnya wilayah perairan Indonesia yang harus diawasi dan modus-modus penyelundupan yang senantiasa berkembang juga menjadi pertimbangan dilakukannya pengaturan kembali organisasi PSO.

Secara umum fungsi-fungsi yang ada dalam struktur PSO DJBC saat ini sudah cukup menunjang tugas pokok dan fungsi DJBC di bidang pengawasan. Namun demikian guna efisiensi dan efektifitas tugas operasional maka dipandang perlu untuk melakukan penajaman fungsi-fungsi tertentu di dalam struktur organisasi PSO yang saat ini ada. Dengan kekuatan sarana patroli yang dimiliki oleh DJBC saat ini, maka unit-unit operasional yang memiliki tanggung jawab di bidang pengawasan yang merupakan user dari PSO harus jeli dalam membuat perencanaan dan pengelolaan pola patroli dan operasi, termasuk memperbaiki koordinasi pengawasan antar unit terkait untuk dapat menjawab tantangan pengawasan. Saat ini DJBC memiliki tiga PSO yang tersebar di tiga wilayah yaitu PSO Tipe A Tanjung Balai Karimun Kepulauan Riau dengan Kantor Wilayah Atasan yaitu Kanwil DJBC Khusus Kepulauan Riau, yang memiliki wilayah operasi meliputi Kanwil DJBC DJBC Nangroe Aceh Darussalam, Kanwil DJBC Sumatera Utara, Kanwil DJBC Riau dan Sumatera Barat, Kanwil DJBC Khusus Kepulauan Riau, Kanwil DJBC Sumatera Bagian Selatan, Kanwil DJBC Kalimantan Bagian Barat dan Kantor Pelayanan Utama Tipe B Batam. Sedangkan PSO Tanjung Priok Tipe B Jakarta dengan kantor atasan Kanwil DJBC Jakarta, memiliki wilayah operasi meliputi Kanwil DJBC Banten, Kanwil DJBC Jakarta, Kanwil DJBC Jawa Barat, Kanwil DJBC Jawa Tengah dan Daerah Istimewa Yogyakarta, Kanwil DJBC Jawa Timur I, Kanwil DJBC Jawa Timur II, Kanwil DJBC Bali, NTB dan NTT, serta Kantor Pelayanan Utama Bea dan Cukai Tipe A Tanjung Priok. Sementara PSO Pantoloan Tipe B, Sulawesi Tengah dengan kantor wilayah atasan Kanwil DJBC Sulawesi, memiliki wilayah operasi Kanwil DJBC Kalimantan Bagian Timur, Kanwil DJBC Sulawesi dan Kanwil DJBC Maluku, Papua dan Irian Barat. 


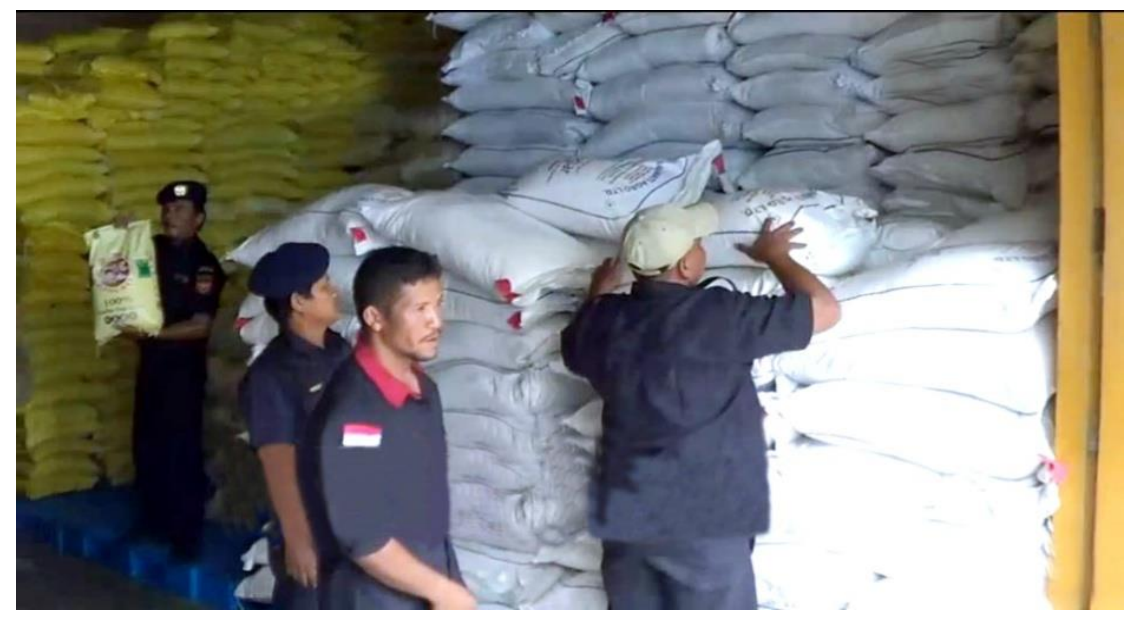

Gambar 3. Hasil Observasi 1

Gambar diambil pada saat penyitaan hasil penyelundupan sembako wilayah kanwil DJBC Kepulaun Riau. Dari Gambar 4.3 tersebut terlihat bahwa adanya upaya penyelundupan beras ke wilayah Indonesia oleh importir melalui jalur Kepulauan Riau yang berbatasan langsung dengan selat Malaysia. Seperti diketahui, pintu masuk resmi di Indonesia hanya lima yakni pelabuhan Belawan di Sumatera Utara, pelabuhan Tanjung Priok Jakarta, Bandara Soerkarno-Hatta Tangerang, pelabuhan Tanjung Perak, Surabaya dan pelabuhan Makassar, Sulawesi Selatan. Hasil penyelundupan sebanyak 6 ton beras dan sembako tersebut berhasil di gagalkan oleh DJBC Kepri. Dengan berbendera Indonesia kapal ini dibekuk di perairan kelingking Pulau Abang Batam. Rencananya 6 ton beras ini akan dibawa ke Lingga Kepulauan Riau.

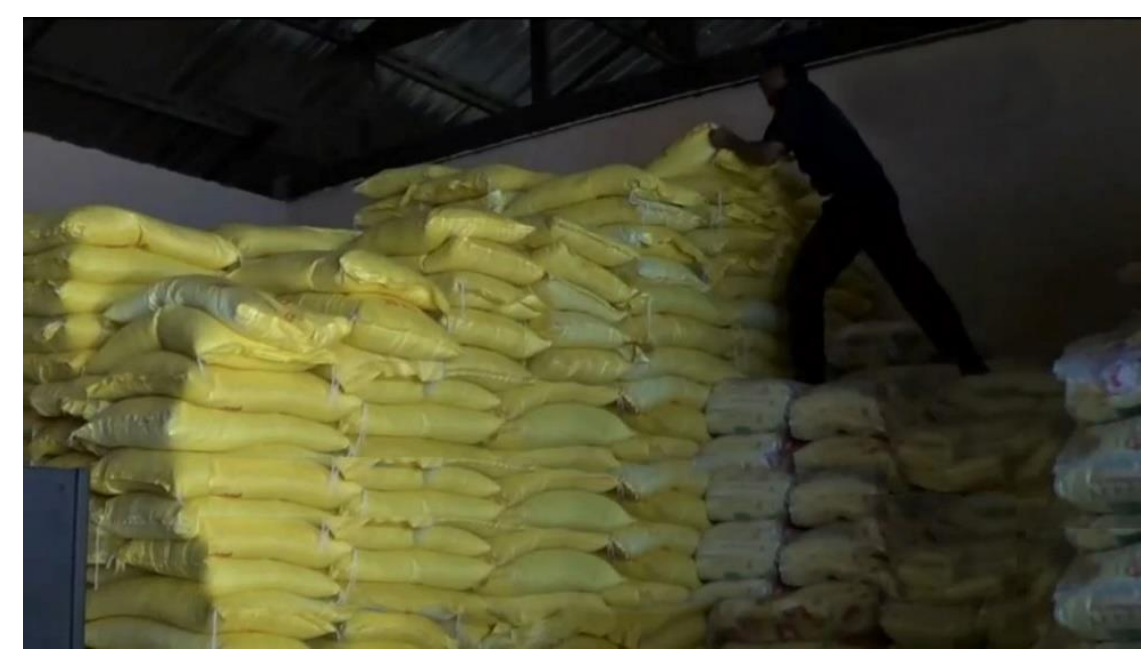

Gambar 4. Hasil Observasi 2 
Modus penyelundupan importir memuat barang asal kawasan bebas kedaerah pabean lainnya. Selain itu importir melakukan kegiatan lainnya yang tidak resmi tanpa adanya pemberitahuan dan biasanya dilakukan melalui pelabuhan pelabuhan tikus yang ada di sekitar Pulau Batam. Untuk mengelabui petugas tumpukan bagian atas ditutupi dengan kotak bekas dan minuman ringan, Beras serta sembako di muat di bagian bawah kapal.

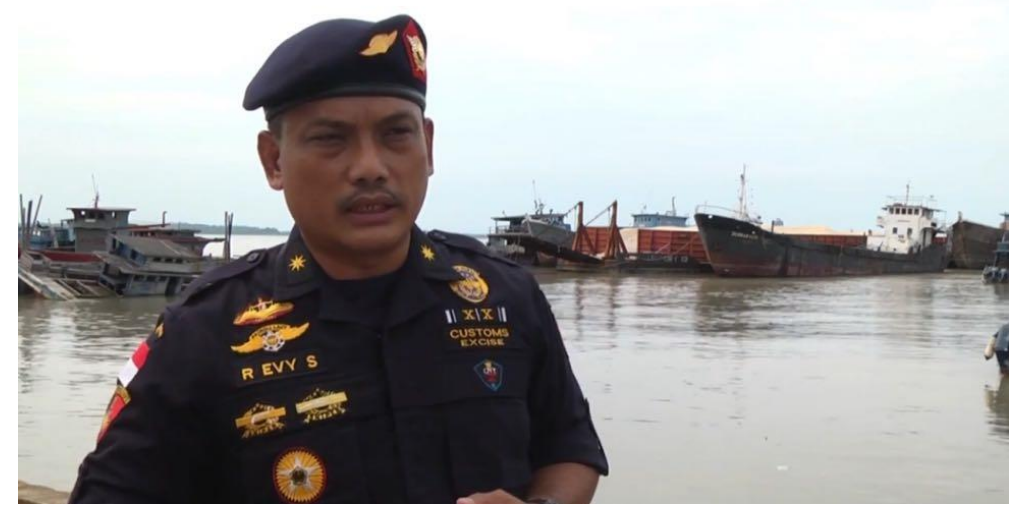

\section{Gambar 5. Hasil Observasi 3}

Menurut petugas DJBC Kepulauan Riau ini adalah tindakan penangkapan yang kedua belas kalinya yang terjadi di wilayah perairan Kepri yang memiliki muatan beras dan sembako eks import Batam dan berhasil di tegah. Dan diperkirakan dengan nilai barang hasil penyelundupan sekitar Rp.100jt. Nakhoda kapal juga telah diamankan dan ditetapkan sebagai tersangka dan guna dilakukannya penyelidikan lebih lanjut kapal ditarik ke dermaga bea cukai Tg. Balai Karimun.

Dalam rangka pelaksanaan pengawasan lalu lintas barang di setiap titik pelabuhan di Kota Batam, diperlukan pengawasan yang sangat efektif oleh pemerintah kota dalam hal penelitian dokumen dan pemeriksaan fisik barang. Sementara itu dari segi pemerintahan yang bercirikan good governance (tata kelola pemerintahan yang baik) pengawasan merupakan aspek penting untuk menjaga fungsi pemerintahan berjalan sebagaimana mestinya. Pengawasan harus menjadi prioritas untuk menciptakan good governance itu sendiri. Ini akan erat kaitannya dengan akuntabilitas publik, fungsi pengawasan juga merupakan salah satu cara untuk membangun dan menjaga legitiminasi warga masyarakat terhadap kinerja pemerintahan dengan menciptakan suatu sistem pengawasan yang efektif baik pengawasan internal maupun pengawasan eksternal disamping mendorong adanya pengawasan masyarakat.

Untuk wilayah Batam terdapat tiga pelabuhan resmi untuk bongkar muat barang, yaitu Pelabuhan Sekupang, Pelabuhan Kabil dan Pelabuhan Batu Ampar. Pelabuhan Batu Ampar merupakan pelabuhan paling besar bongkar muat barang disana. Seluruh barang yang paling banyak masuk adalah barang untuk Kepentingan Industri dan beberapa perusahaan elektronik, perusahaan makanan dan sembako juga memasok barang dari situ. Semua barang bercampur tanpa ada pola penyusunanan yang terstruktur. Dampaknya sangat luas dan berat bagi 
perekonomian masyarakat, disamping itu juga akan mempengaruhi keamanan dan stabilitas nasional akan terganggu. Hal ini didasarkan oleh sekelompok kecil orang-orang yang tidak bertanggung jawab dimana para pelaku semata - mata hanya untuk mencari keuntungan diri sendiri maupun kelompok.

Pencanangan Batam sebagai Kawasan Perdagangan Bebas dan Pelabuhan Bebas sebagaimana yang dituangkan dalam UU No.36 tahun 2000 yang diubah dengan UU No.44 tahun 2007 serta PP No.2 tahun 2009. hal ini memberikan harapan yang besar bagi pertumbuhan perekonomian yang sangat menarik, karena dalam penerapan Batam sebagai Free Trade Zone telah memiliki payung hukum yang kuat dan menjadi hukum positif yang harus dilaksanakan oleh masyarakat Indonesia, khususnya penarapannya di Batam. Menjelang pemberlakuan FTZ dan Free Port, Pemerintah dan pengusaha serta seluruh "stakeholders" di Kota Batam harus mengantisipasi pesatnya pertumbuhan di dua lini ekonomi. Eksistensi "dual economy" di sektor formal dan informal dan termasuk juga bisnis illegal dan transaksi illegal. Jika model implementatif FTZ melalui kebijakan di Dewan (regulator FTZ) dan Badan Pengusahaan Kawasan (operator FTZ) semakin proinvestasi maka arah kebijakan FTZ akan menuai eskalasi bisnis di sektor riil. Hampir semua sektor ekonomi akan terangkat yang didahului dengan ekspansi sektor industri manufakturing di 26 kawasan industri dan 67 perusahaan galangan kapal di Kabil, Batu Ampar, Sekupang, dan Tanjung Uncang. Namun tingginya permintaan akan barang sebagai akibat "booming economy" juga membuka peluang masuknya barang secara illegal atau barang atau lolosnya produk, komoditas atau barang yang masuk dalam "negatif list" impor/ekspor.

Tindak pidana penyelundupan di Indonesia di pengaruhi oleh beberapa faktor yang saling mempunyai hubungan kausal. Faktor-faktor tersebut meliputi:

\section{Faktor Geografis.}

Dengan banyaknya pulau di indonesia terutama Kepri terdiri dari ribuan pulau besar dan kecil,dan bahkan dapat kita lihat dengan garis pantai yang terbentang luas dan yang sangat berdekatan dengan negara-negara tetangga singapore,Malaysia yang sudah lebih dahulu mengalami kemajuan baik di bidang perkebunan, maupun industri dan membuka kesempatan atau peluang, atau bahkan dapat merangsang para pengusaha (lokal maupun asing) untuk melakukan penyelundupan. Keadaan ini misalnya terutama di manfaatkan oleh para penyelundupan di sekitar kepulauan Riau, Batam,terutama yang menjadi target bagi para pengusaha yang berada di dekat Kepulauan Riau, dan ada juga ke daerah lain seperti Tanjung Pinang.

\section{Kondisi Industri Dalam Negeri}

Memang Batam menjadi daerah yang lebih dulu maju di bidang industri di bandingkan dengan daerah lain di sekitarnya,dengan kondisi industri yang bersaing ketat dengan Negara lain seperti Malaysia,sehingga turut pula mempengaruhi tingginya biaya produksi menjadikan hasil produksi kurang mampu bersaing dengan barang-barang hasil luar negeri. Sehingga sangat rentan timbulnya tindak pidana penyeludupan,karena sebagaimana ketahui produksi industri dalam negeri pada umumnya masih dalam tahap 
perkembangan sehingga hasilnya pun masih belum dapat di andalkan,keadaan ini di tambah lagi dengan tingginya biaya transportasi dan minimnya sarana pengangkut sehingga dapat menyebabkan hambatan dalam distribusi. Harga barang-barang buatan RRC jauh lebih murah dibandingkan dengan barang-barang yang sama produksinya dalam negeri, sehingga dalam hal ini pemain kepulauan Riau terutama Batam,seringkali menjadi cela untuk,melakukan penyeludupan. Sehingga hal ini tidak kurang membuat bingung para pengusaha dan pengambil keputusan di negara kita. Keadaan seperti ini menggambarkan bahwa hasil produksi dalam negeri masih belum mampu bersaing dengan barang-barang hasil produksi impor. Dengan adanya disparitas harga antara produk lokal dengan produk impor membuka kemungkinan para penyelundup melakukannya.

\section{Sumber Daya Alam (SDA)}

Adanya beberapa faktor sumber daya Manusia Indonesia terutama di Batamseringkali terjadi penyeludupan seperti hal Sembako misalnya. Hal ini bisa di perhatikan dengan banyaknya industri-industri yang berada di kawasan pabean atau Free Trad Zone (FTZ) sehingga dapat di lihat berupa yang di inginkan Pulau-pulau yang berada di sekitar Batamuntuk sumber komoditi yang bersangkutan,seperti beras,minuman, dan lain-lain,yang kesemuanya ini sangat di butuhkandi karenakan Batam merupakan daerah yang sudah lebih maju di bandingkan dengan daerah yang lain sehingga seringkali terjadi saingan dalam melakukan pemasaran,untuk melempar hasil industrinya yang tidak jauh dari Pulau Batam,maka masalah penyeludupan menjadi semakin menarik bagi pengusaha yang tidak bertanggung jawab untuk memanfaatkan,kesempatan yang ada.Jadi dalam hal ini sangatlah di butuhkan sumber daya Manusia yang berpikir secara maju untuk tidak melakukanh penyeludupan Sembako karena kosumsi Batam sendiri masih kurang.

\section{Kelebihan Produksi}

Seperti hal di Malaysia yang telah maju dan mapan di sektor industri dan perekonomiannya ada kalanya mengalami kelebihan produksi (over production) misalnya Negara malaysia seringkali mengalami kesulitan dalam memasarkan hasil- hasil produksinya. Keadaan ini oleh para pengusaha yang tidak bertanggung jawab lalu dimanfaatkan untuk kepentingan dan keuntungan sebesar-besarnya dengan cara yang tidak sah atau ilegal, yaitu berusaha memasukan barang - barang dagangan mereka ke negara-negara lain melalui penyelundupan,terutama ke Kepri dan BatamBahkan beberapa negara-negara tertentu melakukan politik dumping sehingga kedatangan barang-barang impor ke negara-negara yang belum stabil hasil 40 produksinya mengalami keguncangan-keguncangan menghadapi persaingan barang- barang produksi impor. Hal ini bisa terjadi karena di samping barang-barang ekspor impor tersebut sangat dibutuhkan masyarakat seperti bawang Merah dan juga baik mutu maupun harganya kadang-kadang jauh lebih baik dan lebih murah dibanding produksi dalam negeri, dan apabila keadaan ini terjadi maka bagi masyarakat sendiri tidak mempersoalkan lagi apakah barang-barang yang dibelinya itu 
dimasukan secarah sah tau tidak, apalagi daya beli masyarakat kita memang masih rendah. Nah keadaan ini akan dimanfaatkan oleh para pengusaha yang tidak bertanggung jawab untuk memasukan barang-barang yang di butuhkan oleh masyarakat tersebut secara ilegal (penyelundupan).

\section{Transportasi}

Ini juga menjadi masalah penyelundupan akan ditentukan pula oleh faktor transportasi. Daerah - daerah tertentu di pulau Batam dalam mendatangkan barang- barang kebutuhan pokok masyarakat sering mengalami keterlambatan, disebabkan belum lancarnya hubungan antara satu pulau dengan pulau lainnya. Bahkan seperti pulau Natuna,sarasan,Midai, dan lain-lain beberapa waktu lampau sering tergantung pada keadaan alam (cuaca) apabila ingin mendatangkan barang-barang kebutuhan sehari-hari ke daerah tersebut karena hubungan darat dari daerah lain memang belum tersedia. Akibatnya masyarakat di daerahdaerah terpencil serupa itu sering memasukan barang-barang kebutuhan pokoknya secara tidak sah (kadang-kadang dibawa oleh kapal besar asing).Hal ini ditambah lagi dengan letak di daerah-daerah (pulau-pulau) tertentu di Kepulauan Riau memang berdekatan dengan negara-negara tetangga. Luasnya wilayah kepulauan serta banyaknya daerah-daerah kita yang belum lancar sarana transportasinya jelas membuka peluang para penyelundup untuk melakukan aksinya, hal ini ditambah lagi dengan letak kepulauan - kepulauan tersebut yang sangat berdekatan dengan negara-negara tetangga kita yang industrinya telah terlebih dahulu mengalami kemajuan.

\section{Mentalitas}

Kepulauan Riau terutama Batam yang kaya dengan perusahaan hebat dengan fasilitas di bidang Metal,Pabrikasi,dengan kekayaan sumber manusianya sehingga dapat bersaing dengan daerah lain, penduduk yang banyak, boleh berbangga dan bersyukur atas rahmat Tuhan itu. Akan tetapi jika yang mengendalikan dan mengelola semua sumber daya itu tidak jujur, maka bukan tidak mungkin Pulau Batam yang kita cintai ini akan tetap menderita sebagai pulau yang aturan hukumnya ngambang dan penuh drama serta menjadi miskin. Para pelaku atau penyelundup umumnya bukanlah orang-orang atau pengusaha bermodal kecil,melainkan orang- orang yang bermodal besar. Jadi, apabila mental para petugas kita dalam menghadapi bujukan dan rayuan oknum oknum penyelundup tersebut tidak kuat dan teguh, sudah barang tentu menjadi makanan empuk bagi penyelundup yang memiliki otak yang lihai dan licik.

\section{Masyarakat}

Penaggulangan tindak pidana peyelundupan sering dirasakan kurangnya partisipasi dari warga masyarakat Batam, meskipun media massa telah cukup gencar membuat berita-berita tentang pemberantasan tindak pidana penyelundupan, mungkin hal ini disebabkan karena warga masyarakat Batam merasa beruntung karena dapat membeli barang-barang ekspor luar negeri asal selundupan dengan harga murah dan mutu yang tinggi. Keadaan ini dapat kita saksikan dahulu sewaktu masih ramainya pasar seken tanjung sengkuang,Batu mera,di mana banyak sembako dari singapore, jepang dan taiwan di jual dengan 
harga jauh di bawah pasaran. Hal ini disebabkan oleh warga masyarakat Batam haus akan barang-barang bermutu sedangkan daya beli masyarakat sendiri masih rendah. Dan juga di sebabkan konsumen barang-barang mewah di Indonesia semakin meningkat jumlahnya akibat kemajuan teknologi serta kecenderungan anggota masyarakat tertentu ke arah masyarakat prestige. Kenyataan di atas, di mana kebutuhan akan barang-barang mewah produksi luar negeri semakin meningkat, akan dimanfaatkan oleh para penyelundup, dengan melakukan penyelundupan atas barang-barang mewah tersebut, karena tokoh masyarakat menghendakinya.

Tidak bisa dipungkiri bahwa setiap kebijakan ekonomi selalu berimplikasi positif dan negatif. Salah satu efek FTZ menyeluruh (the black shadow of FTZ) yang harus diantisipasi adalah berkembangnya bisnis gelap (illegal trading). Kejadian dalam satu tahun terakhir, Media Cetak dan Elektronik di Kota Batam dan Provinsi Kepulauan Riau diramaikan dengan berita praktek dan modus operandi "illegal business" di perairan sekitar dan di dalam kawasan FTZ/Freeport. Misalnya adanya kasus penyeludupan senilai Rp.8 miliar atas 2.400 dus rokok Gudang Garam yang dibawa KLM Tri Sejahtera di Perairan Tanjung Berakit, penangkapan 70 ton solar illegal di Pulau Tanjuk-Subang Mas Batam dibawa oleh KM. Setia senilai Rp.600 juta, penjualan solar bersubsidi di Industri shipyard (PT.UMP) Tanjung Uncang, oleh SPBU Simpang Base Camp, penggeledahan penumpang yang menyeludupkan Rp.100 juta,- dan Rp.686 juta,- dibawa langsung oleh oknum pembisnis "money changer"diseludupkan ke Singapura melalui Pelabuhan Harbor Bay, penyitaan 3.600 botol wine ilegal, kemudian 100 ton solar diamankan,penangkapan 218 Laptop asal Malaysia, juga salah hasil temuan dari penelitian ini bahwa DJBC Kepri melakukan penangkapan untuk yang ke dua belas kalinya dalam penyelundupan sembako di wilayah perairan Batam.

Terdapat 25 pelabuhan yang terdaftar di Dinas Perhubungan Kota Batam (2008) di luar enam pelabuhan rakyat berstatus illegal yang ada. Bahkan status kepelabuhan yang ada masih perlu dibenahi agar sesuai dengan persyaratan yang diatur dalam UU.No. 21 Tahun 1992 tentang Pelayaran juncto UU.No.17 Tahun 2008 tentang Pelayaran atau PP.No.69 Tahun 2001 tentang Kepelabuhanan. Apalagi UU.No.44 Tahun 2007 yang mengatur Batam FTZ juga Batam FPZ (Free Port Zone) maka namanya Kawasan Perdagangan Bebas dan Pelabuhan Bebas.

Praktek penyelundupan identik dengan daerah bertipe perbatasan seperti Batam, lalu lintas sejumlah pelabuhan di Batam yang padat setiap hari masih dimanfaatkan oleh oknum-oknum tertentu untuk mencari keuntungan dengan memasukan barang-barang yang tidak memiliki izin dan surat-surat resmi ke Batam. Aksi penyelundup ini bukan hanya merugikan negara secara finansial tetapi juga melemahkan wibawa pemerintah yang selalu 'dikibuli' oleh para pelaku penyelundupan. Apalagi dengan pemberlakuan Perpu Free Trade Zone (FTZ), Direktorat Bea dan Cukai (BC) ditenggarai bakal kerepotan untuk melakukan pengawasan karena bebasnya barang-barang keluar masuk ke Batam. Kondisi ini diperburuk dengan banyaknya pelabuhan ilegal alias pelabuhan tikus 
di Batam. Data yang dihimpun, sedikitnya tercatat sebanyak 64 titik pelabuhan tikus di Kota Batam. Dari 64 titik tersebut, termasuk diantaranya pelabuhan yang biasanya digunakan masyarakat untuk aktivitas perekonomian skala kecil. Beraneka jenis barang-barang yang tidak dilengkapi dokumen ekspor-impor dan kepabeanan diduga setiap hari wara-wiri masuk ke Batam. Penangkapan yang dilakukan aparat keamanan dan petugas $\mathrm{BC}$ diduga hanya sebagian kecil saja. Sebagian besar barang-barang ilegal itu berhasil diselundupkan melalui puluhan pelabuhan tikus yang tersebar di sejumlah titik di Batam.

Dalam rangka melaksanakan visi dan misi untuk mengembangkan Batam, maka dibangun berbagai insfrastruktur modern yang berstandar internasional serta berbagai fasilitas lainnya, sehingga diharapkan mampu bersaing dengan kawasan serupa di Asia Pasifik. Beberapa tahun belakangan ini sejak digulirkan penerapan Free Trade Zone Batam (FTZ Batam), Bintan, dan Karimun yang mengacu pada UU No 36 tentang Kawasan Perdagangan Bebas dan Pelabuhan Bebas dan kemudian dirubah beberapa kali melalui PERPU, sehingga di undangkan menjadi UU no 44 tahun 2007.

Ada juga Undang-Undang 36 tahun 2000 Tentang " Penetapan Peraturan Pemerintah Pengganti UU No 1 Tahun 2000 Tentang Kawasan Perdagangan Bebas dan Pelabuhan Bebas Menjadi Undang Undang serta masih banyak Undang-Undang lainnya yang berkaitan dengan FTZ Batam.

Sampai saat ini, Patroli Laut Bea Cukai merupakan patroli laut yang paling aktif untuk mengawasi keluar masuknya barang ilegal di sekitar perairan Indonesia. Tentunya ini tidak terlepas dari tugas TNI Angkatan Laut yang selalu siaga penuh untuk menjaga seluruh wilayah perairan Indonesia. Hal ini membuktikan kalau Patroli laut Bea Cukai siap mengamankan Indonesia dari perdagangan ilegal, baik dilakukan secara mandiri maupun yang dilakukan secara koordinasi dengan berbagai instansi terkait untuk menambah keefektifan dan kesiagaan patroli laut. Terlepas dari itu semua, dalam waktu beberapa tahun terakhir ini Patroli Laut Bea Cukai terus mengembangkan diri baik dari sisi sarana dan prasarana yang dimilikinya maupun keandalan personilanya dalam menjalankan tugas di laut. Untuk sarana dan prasarana yang ada, kini DJBC sendiri memiliki 6 jenis kapal patroli dan 5 Pangkalan Sarana Operasi (PSO). Adapun keenam jenis kapal patroli tersebut adalah, Kapal Fast Patrol Boat (FPB) ukuran 60 meter sebanyak 2 kapal, FPB ukuran 38 meter sebanyak 7 kapal, FPB ukuran 28 meter Alumunium 14 kapal, FPB ukuran 28 kayu sebanyak 20 kapal, Verry Slinder Vessel (VSV) ukuran 15 meter sebanyak 10 kapal, dan Speed Boat ukuran 15 dan 10 meter sebanyak 140 kapal. Sedangkan untuk kelima PSO yang dimiliki DJBC saat ini adalah Pertama, PSO Bea Cukai Tipe A Tanjung Balai Karimun dengan daerah pengawasan meliputi Perairan Selat Malaka, Perairan teritorial dan Perairan kepulauan bagian timur dan barat Sumatera, laut Natuna, Selat Bangka, dan Perairan Kepulauan Riau. Kedua, PSO Bea Cukai Tipe B Batam dengan daerah pengawasan Selat Singapura. 
Sejak dijadikannya Batam sebagai Free Trade Zone, Batam mengalami kemajuan yang cukup pesat. Banyaknya industri perkapalan, pelabuhan, perusahaan, serta peti kemas membuat Batam menjadi salah satu daerah tujuan transmigrasi yang semakin hari semakin padat. Hal ini dikarenakan letaknya yang sangat startegis berada di perairan Selat Malaka berbatasan langsung dengan Singapura dan Malaysia. Upaya penanggulangan masalah penyelundupan, dihadapkan pada kendala yaitu adanya hukum pasar dimana banyaknya permintaan di masyarakat akan barang elektronik murah dan up to date serta didukung penawaran dari banyak pengusaha di negara-negara maju seperti Singapura dan Malaysia yang kelebihan produksi dan sulit memasarkan produknya sehingga dijual secara murah dan cepat kepada para pengusaha di dalam negeri melalui jalur yang tidak resmi. Dalam melaksanakan undang - undang kepabeanan kita ini tidak terlalu kaku (rigit), sebagaimana sering dikemukakan oleh Presiden dan para Menteri bahwa pegawai negeri sipil merupakan abdi negara dan masyarakat, tentu kita melayani mereka, dan membuat kemudahan - kemudahan tanpa meninggalkan unsur pengawasan yang melekat kepada setiap pejabat bea dan cukai dalam melaksanakan tugasnya, karena dalam pelaksanaannya sedikit banyak dijumpai hal - hal yang sebaliknya yaitu justru para pejabatlah yang minta dilayani. Kita semua mengetahui bahwa institusi bead an cukai adalah bagian dari pajak, yaitu pajak tidak langsung. Sehingga berbicara mengenai undang - undang kepabeanan dan juga cukai kita tidak dapat lepas / tidak dapat meninggalkan prinsip - prinsip yang dikandung dalam undang - undang perpajakan. Terhadap undang - undang pajak, undang - undang kepabeanan merupakan hukum khusus (lex specialis) dan undang-undang pajak merupakan hukum umum (lex generalis).

Adagium lex specialis derogat lex generali, diartikan bahwa dalam masalah kepabeanan, ada hal yang sama yang diatur oleh hukum yang lain, misalnya hukum perdata ataupun hukum pidana termasuk dalam undang - undang pajak sekalipun, maka yang dipakai adalah aturan yang diatur oleh undang - undang kepabeanan. Tapi sebaliknya apabila ada hal - hal yang tidak diatur oleh undang undang kepabeanan, maka kita mengikuti prinsip-prinsip hukum lain terutama hukum pajak mengingat bahwa undang - undang kepabeanan adalah merupakan bagian dari undang - undang hukum fiskal. Dengan kondisi Kepri yang wilayahnya terdiri dari $96 \%$ perairan dan memiliki 2000 pulau, jadi tantangan sendiri bagi instansi terkait untuk bekerja secara maksimal khususnya bea dan cukai untuk mengantisipasi dan mengatasi penyelundupan dan bekerja sama dengan instansi kepolisian dan instansi perairan laut lainnya untuk mempersempit ruang gerak pelaku penyelundupan sembako di Kota Batam. 


\section{E. Kesimpulan}

Peneliti memperhatikan beberapa kondisi yang peneliti amati di Pulau Batam, sehingga mendapatkan beberapa kesimpulan akhir diantaranya:

1. Pengawasan yang dilakukan oleh Pemerintah Batam dalam hal ini KPU Bea dan Cukai sudah sesuai peraturan undang-undang yang berlaku tetapi masih belum efektif karena belum bisa memenuhi fungsi dari pengawasan itu sendiri yaitu mempertebal rasa tanggungjawab dari pegawai yang diserahi tugas dan wewenang dalam pelaksanaan pekerjaan, mendidik pegawai agar melaksanakan pekerjaannya sesuai prosedur yang telah ditetapkan, mencegah terjadinya kelalaian, kelemahan, dan penyimpangan agar tidak terjadi kerugian yang tidak diingingkan, dan memperbaiki kesalahan dan penyelewengan agar dalam pelaksaan pekerjaan tidak mengalami hambatan-hambatan.

2. Pelanggaran penyelundupan Sembako dan proses penetapan barang bukti menjadi Barang Dikuasai Negara sesuai ketentuan Pasal 53 ayat 4 UU Nomor 10 Tahun Tahun 1995 tentang Kepabeanan sebagaimana diubah dengan Undang-Undang Nomor 17 Tahun 2006 dan Pasal 37 ayat 2 Peraturan Pemerintah Nomor 10 Tahun 2012 Tentang Keberlakuan Kepabeanan, Perpajakan, Dan Cukai Serta Tata Laksana Pemasukan dan Pengeluaran Barang Ke Dan Dari Serta Berada Di Kawasan Yang telah Di Tetapkan Sebagai Kawasan Perdagangan Bebas Dan Pelabuhan Bebas.

3. Pemerintah Pusat dalam hal ini KPU Bea dan Cukai di Kota Batam dalam menangani fungsi pengawasan. Namun berbagai kondisi, dari kondisi geografis hingga tingginya konsumtif masyarakat terhadap barang-barang impor sehingga sulit untuk diajak bekerja sama ditambah wilayah pelabuhan Batam merupakan kawasan bebas FTZ hingga keburukan-keburukan moral internal oknum yang tidak bertanggung jawab di pelabuhan sehingga terjadi praktek suap menyuap membuat kapasitas pengawasan pun menjadi lemah. Kantor Pelayanan Utama Bea dan Cukai dilengkapi sumber daya manusia dengan sarana dan prasarana yang ada dalam menjalankan fungsi pengawasan di pelabuhan sudah berusaha semaksimal mungkin. Namun dilapangan kondisi wilayah geografis yang luas dengan keterbatasan SDM juga membuat mereka masih menemukan hambatan-hambatan eksternal maupun internal. 


\section{DAFTAR PUSTAKA}

\section{Buku}

Aridhayandi, M. R. Kajian tentang Penerapan Sanksi Pidana terhadap Pelaku yang Melakukan Perbuatan Curang dalam Bisnis Dihubungkan dengan Pasal 379a Kitab Undang-Undang Hukum Pidana, 8(65), 2014

Abidil, Zainal, Modul Tugas dan Fungsi Direktorat Jendel Bea dan Cukai, Pusdiklat Bea dan Cukai, Jakarta. 2000

A.M. Kadarman, Jusuf Udara, Pengantar Ilmu Manajemen, Prenalindo, Jakarta.

Batam Indonesia Free Trade Zone Authority, Edisi I Volume XXVII, Diterbitkan oleh Pusat Pengelolaan Data \& Sistem Informasi (PPDSI), BP Kawasan Perdagangan Bebas dan Pelabuhan Bebas Batam. 2015

Badan Pengkajian dan Pengembangan Kebijakan Perdagangan Pusat Kebijakan Perdagangan Luar Negeri Jakarta, Kajian Kebijakan Penentuan Pelabuhan Tertentu Sebagai Pintu Masuk Impor Produk Tertentu, Jakarta. 2012

Herdiansyah, Haris, Metode Penelitian Kualitatif, Jakarta: Salemba Humanika. 2010

Husaini, Usman, Manajemen, Teori, Praktek dan Riset Pendidikan, Jakarta: Bumi Aksara. 2001

Irfan Fachrudin, Pengawasan peradilan Administrasi Terhadap Tindakan Pemerintah, Bandung: PT. Alumni, 2004.

Khanata, Menuju Batam yang lebih Cemerlang, Jakarta: Pustaka LP3ES, 2003

Lesar, Abdul karim, Menembus Kebuntuan FTZ Batam, Jakarta: UI-Press, 2003

Ndraha, Taliziduhu, Kybernoplogy Ilmu Pemerintahan Baru, Jakarta: Rineka. Cipta, 2011.

Sastrohadiwiryo, B.Siswanto, Manajemen Tenaga Kerja Indonesia, Jakarta: Bumi Aksara, 2003

Sayuti. Arah Kebijakan Pembentukan Hukum Kedepan (Pendekatan Teori Hukum Pembangunan, Teori Hukum Progresif, dan Teori Hukum Integratif). AlRisalah, Jurnal Ilmu Hukum, 13(2), 139-162, 2013

Suparta, I. K. Upaya Badan Narkotika Nasional (Bnn) Dalam Menanggulangi Tindak Pidana Penyelundupan Narkotika Oleh Warga Negara Asing (Study Di Badan Narkotika Nasional Provinsi Bali), 1-13. 2015

Syahputra, A. Pertanggung Jawaban Pidana Terhadap Tindak Pidana Penyelundupan. ILMU HUKUM, 3(1), 2012 


\section{Jurnal / Bahan Kuliah / Kamus / Ensiklopedia}

Angkat, H. A. K. A. Lex et Societatis , Vol. II/No. 7/Ags/2014. Lex et Societatis, II(7), 61-71, 2014

Vargas, E. W., \& González, S. V. (2015). Regulatory challenges for preventing firearms smuggling into Mexico. Mexican Law Review, 7(2), 63-81. https://doi.org/10.1016/S1870-0578(16)30003-8

Wahyuniarti Prabowo, D. (2014). Pengelompokan Komoditi Bahan Pangan Pokok Dengan Metode Analytical Hierarchy Process Classification of Staple Food Commodity Using Analytical Hierarchy Process. Jurnal Kemendag, $163-182$.

Kamus Umum Bahasa Indonesia, Cet. Keempat, Jakarta: Perum dan Percetakan Balai Pustaka, 1995

\section{Peraturan Perundang - undangan}

Undang-Undang No.17 Tahun 2006 Perubahan Atas Undang-Undang Nomor 10 Tahun 1995 tentang Kepabeanan.

Undang-Undang No. 44 Tahun 2007 tentang Penetapan Peraturan Pemerintah Pengganti Undang-undang (Perpu) No 1 Tahun 2000 menjadi Undangundang. Dengan status pelabuhan bebas dan didukung oleh zona perdagangan

Peraturan Menteri Keuangan nomor 74/PMK.01/2009 tentang organisasi dan Tata Kerja Instansi Vertikal Direktorat Jenderal Bea dan Cukai

Peraturan Pemerintah RI No 10 Tahun 2012 pasal 1 ayat 6 yaitu "Kawasan Pabean" 